EDITORIAL

\title{
Information overload in haematology and wine
}

(c) The Author(s), under exclusive licence to Springer Nature Limited 2021

Bone Marrow Transplantation (2021) 56:2873-2875; https://doi.org/ 10.1038/s41409-021-01451-2

Can doctors give patients too much information? Yes, they can. There is no doubt that doctors adopted a patronising attitude to patients, until relatively recently, but perhaps the pendulum has swung too far in the opposite direction. Of course, important information should be given to patients but giving all the information about the disease or its treatment and asking the patient to choose is surely counter-productive. How can a patient, sometimes suffering from a grave and life-threatening illness, be expected to make a decision about the treatment which has taken the doctor many years to assimilate? Patients come to doctors for advice, which should be given after a thorough explanation of how the doctor has reached his/her conclusion. As the late Professor Aidan Halligan (1957-2015) perceptively observed: 'Patients want to know how much you care before they want to know how much you know'.

When I was an active haematopoietic cell transplanter (HCT) I used to spend long-time counselling patients and giving them a list of possible complications associated with the procedure. I remember two things clearly. When I mentioned infertility (following myeloablative conditioning), almost inevitably and understandably, female patients began to cry. My second memory was that at the end of the interview I would ask: 'Are there any questions?' This was invariably met with the question: 'what would you do doc?'. However, there probably is a cultural difference in how much a patient wants to know [1]. What constitutes enough, but not too much, information for a patient, is a matter of fine judgement but should be driven by experience and an assessment of the ability of the patient to understand, rather than a fear of litigation. Perhaps Shakespeare was correct when he said: 'Let's kill all the lawyers' [2].

What doctors say and what patients hear is a phenomenon with which most physicians are familiar. A useful strategy is to ask the patient to repeat, in his/her own words, what you have just explained. It is interesting to note how words are 'lost in translation'. I often found that a simple diagram, illustrating what you have said, is very useful in avoiding confusion and clarifying meaning. As physicians, we know that 'what doctors say and patients hear' are often very different.

One of the most important, yet underestimated interactions between a patient and a doctor is tactile communication. From a simple hand-shake, where appropriate, to a physical examination, a very important bond is created. As my mentor at the University of Minnesota, Professor Harry Jacob would say: 'look at the patient; he/she is giving you the diagnosis'. I cannot speak for all jurisdictions but in my country and my nearest neighbour, it seems that examining patients is no longer felt to be necessary.

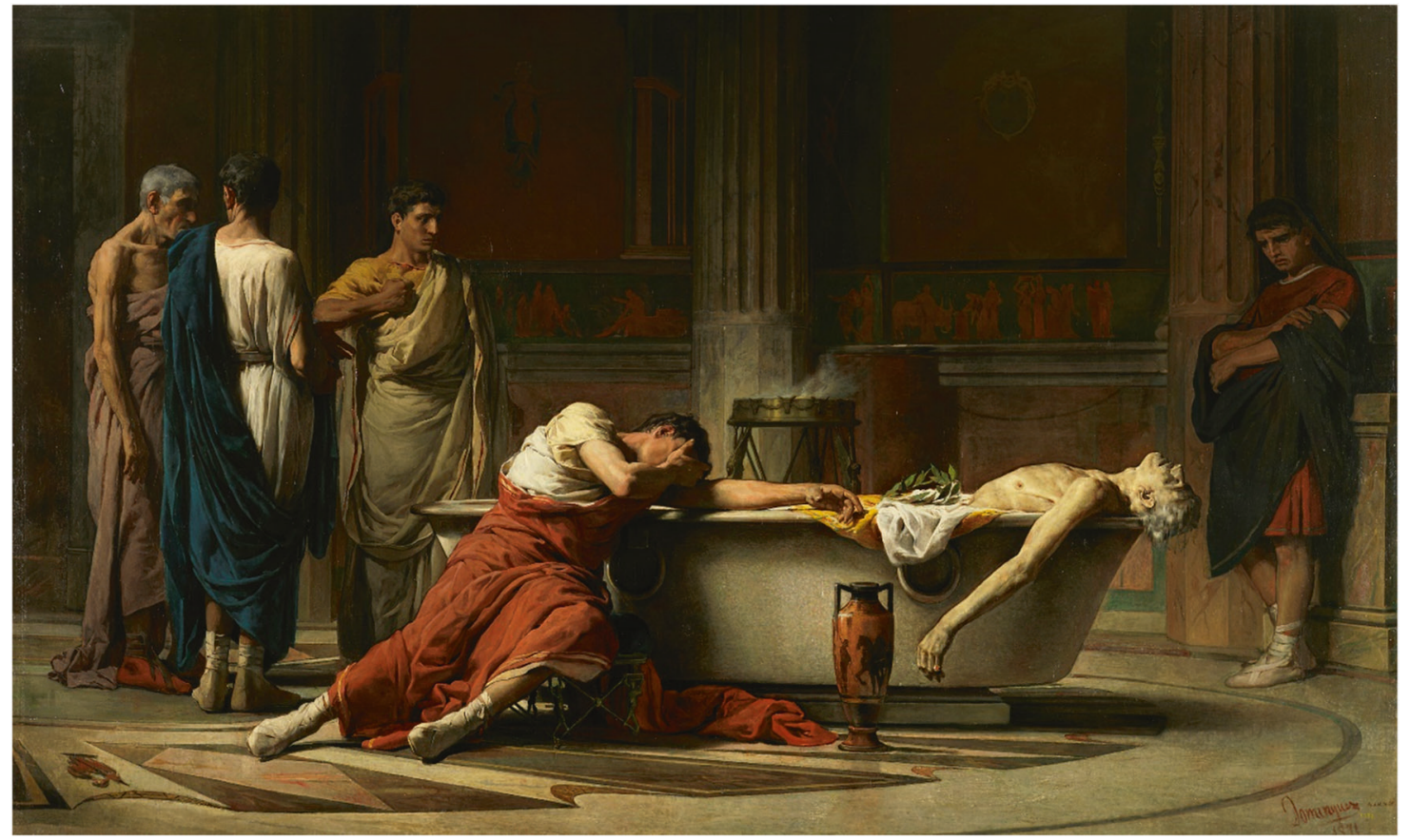

Fig. 1 Seneca. The death of Seneca. Manuel Domínguez Sánchez, 1871. Public Domain. Museo del Prado, Madrid, Spain.

Received: 19 July 2021 Revised: 23 July 2021 Accepted: 23 August 2021

Published online: 3 September 2021 


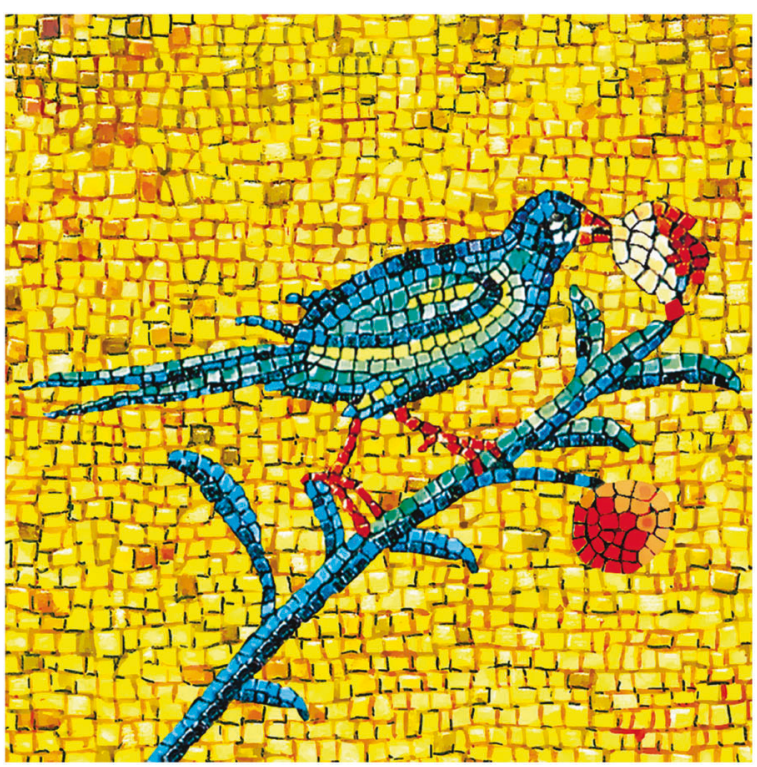

Fig. 2 Wine label. Byzantine mosaic of a birdeating grapes. Used on bottles of Fiano di Avillino from Feudi di San Gregorio, Campania, Italy.

I can attest to many examples of patients going to their family doctors or highly qualified consultants and after a brief history, being given a note for various blood and radiological investigations and NEVER being subjected to a physical examination [3].

The recent pandemic, where understandably, many consultations between patient and doctor, are by means of a telephone or Zoom, will probably increase the chances of patients not being examined in the future.

Can information overload, as it is now called, be an issue in wine labelling? Yes, it can. The term information overload was used in modern parlance by Bertram Gross in his book, The Managing of Organisations: The Administrative Struggle [4]. In 2021 Jancis Robinson wrote an article: 'What's really in your glass? [5] in which she lauds the prospect of an EU plan to list ingredients and nutritional (calorie counts) on the back label of all wines. At present we have alcohol warnings and: 'This wine contains sulphites'. All wine contains sulphites which are present in grapes and may be added to keep the wine fresh and stable. Whether it contributes to headaches, after imbibing wine, is still unclear. Apparently, wine ingredients will shortly be in a digital format within the EU. For most wine drinkers it suffices to know the grape variety in the wine they are drinking. Although Australia brought in the convention of including the grape variety on the label in the 1970s, and this was followed by many countries, it is surprising to find that many wines, especially from France, still do not include this minimal information on the label. I recently consumed two wines from France and one from Spain, two bought in a supermarket and one from a wine importer. In spite of copious information on the label (of dubious value), there was no mention of the grape variety! I'm sure the information on the bottle pleased some faceless regulatory bureaucrat.

Besides information about ingredients is there any other function that wine labels perform? Well, wine labels, like book covers [6] help to sell bottles on the crowded shelves of wine shops and supermarkets. During a recent conversation with the proprietor of a well-known wine shop in suburban Dublin I was told: 'This wine won't sell because of its label'. Most of us think that we are not influenced by wine labels but the industry thinks we are.

In order to appeal to younger customers, a number of winemakers have used wine labels designed by famous artists.

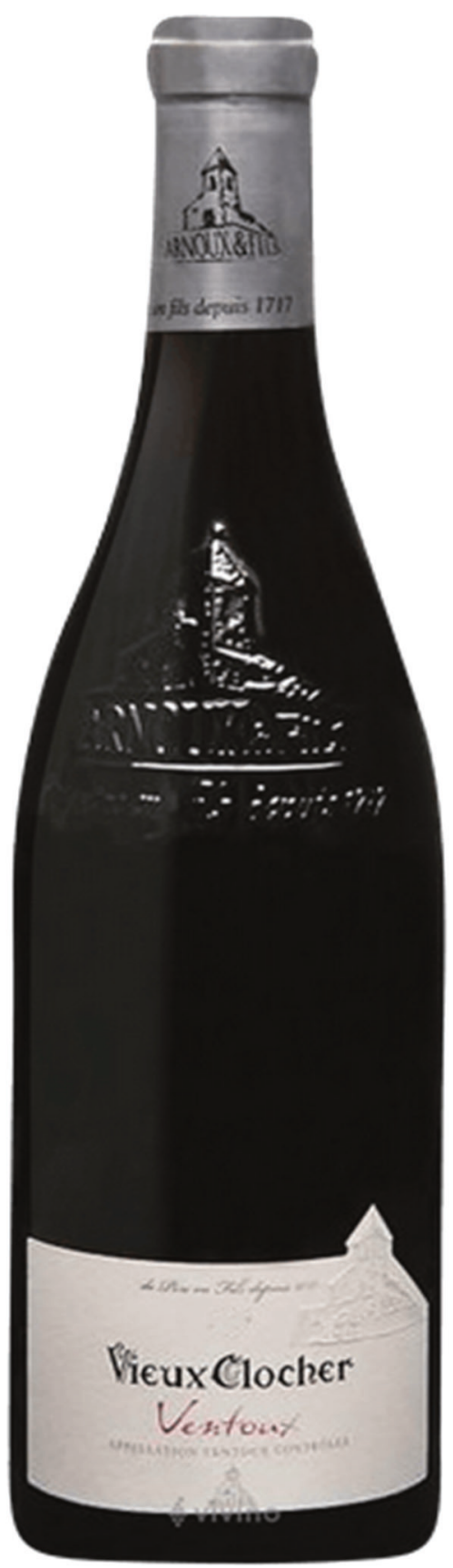

Fig. 3 Ventoux. A bottle of Vieux Clocher, Ventoux from Arnoux et Fils, Vacqueyras, France.

Veuve Clicquot has recently launched 'La Grande Dame' champagne with a label designed by the Japanese artist Yayoi Kusama. Interestingly, the label is still yellow which will presumably enhance its recognisability. One of the earliest uses of artists to design wine labels was Baron Phillipe de Rothschild in 1945. My good friends in Nittardi in Tuscany also use famous artists to design their labels. There are thousands of different wine labels but my personal favourite is the use of Byzantine mosaics by Feudi di San Gregorio in Campania, Italy Fig. 2.

Getting back to the information on wine labels we recently consumed a very nice bottle of Vieux Clocher, Ventoux, Arnoux et Fils, 2019 with dinner, imported into Ireland by my good friend Killian Robinson Fig. 3. The back label contains a vast amount of information in very small print and it eventually confirmed that 
the wine was a blend of Grenache, Syrah, Carignan and Cinsault. It was an excellent blend and a perfect dinner companion.

Question: who was the first person who claimed to climb Mount Ventoux, according to himself, in Provence, for pleasure? He wasn't French!

\section{Shaun R. McCann iD $^{1 凶}$ \\ ${ }^{1}$ Emeritus, Department of Haematology, Trinity College Dublin, Dublin, Ireland. ${ }^{\boxplus}$ email: shaunrmccann@gmailcom}

\section{REFERENCES}

1. D'Souza A, Pasquini M, Spelly R. Is 'informed consent' an 'understood consent' in hemopoietic cell transplantation? Bone Marrow Transpl. 2015;50:10-14.

2. Shakespeare W. Henry VI, part two. The Norton Facsimile. H W Norton \& Company Inc. New York. USA: The Hamlyn Publishing Group Ltd. 1968.

3. Zaiman JAB. The enduring value of the physical examination. Med Clin North Am. 2018;102:417-23.

4. Gross BM. The managing of organisations: the administrative struggle. New York, USA: The Free Press of Glencore. 1964
5. Robinson J. What's really in your glass? FT.com/magazine. London EC4M 9BT, UK: The Financial Times Limited. 2021.

6. McCann SR. Art, labels and wine: you can't judge a book by its cover. 2019. Bone Marrow Transpl. https://doi.org/10.1038/s41409-019-0517-1.

\section{COMPETING INTERESTS}

The authors declare no competing interests.

\section{ADDITIONAL INFORMATION}

Correspondence and requests for materials should be addressed to Shaun $\mathrm{R}$ McCann.

Reprints and permission information is available at http://www.nature.com/ reprints

Publisher's note Springer Nature remains neutral with regard to jurisdictional claims in published maps and institutional affiliations. 